\title{
Penerapan Metode Think Pair Share untuk Meningkatkan Hasil Belajar dan Pengembangan Kreatifitas Koginitif Anak
}

\author{
Kemari
}

TK Al Hidayah Ngadirejo

Email: kemarikemari@gmail.com

\begin{tabular}{l}
\hline Tersedia Online di \\
http://www.jurnal.unublitar.ac.id/ \\
index.php/briliant \\
\hline Sejarah Artikel \\
\hline Diterima pada 2 Juli 2017 \\
Disetuji pada 14 Juli 2017 \\
Dipublikasikan pada: 2 Agustus \\
2017 Hal 344-355 \\
\hline
\end{tabular}

Kata Kunci:

Think pair share, hasil belajar, kreatifitas.

\begin{abstract}
Abstrak: Tujuan penelitian untuk meningkatkan hasil belajar dan kreatifitas anak dalam pengembangan kognitif melalui metode Kooperatif Think Pair Share pada anak TK Alhidayah Ngadirejo Kec. Kepanjenkidul. Hasil penelitian menunjukkan ada peningkatan hasil belajar anak yang berupa pemahaman konsep bilangan menjadi $86,6 \%$ pada siklus II. Kreatifitas anak dalam aspek ketrampilan bertanya, bekerjasama, ketepatan menjawab dan tanggung jawab menjadi $100 \%$ pada siklus II, Berdasar hasil penelitian tersebut dapat disimpulkan bahwa pembelajaran kooperatif Think Pair Share dapat meningkatkan hasil belajar dan kreatifitas anak. Hasil penelitian ini memiliki harapan agar guru menerapkan pembelajaran kooperatif dalam mengajarkan bidang pengembangan di Taman Kanak-Kanak.
\end{abstract}

Tujuan pendidikan di Taman Kanak-Kanak adalah agar anak dapat tumbuh dan berkembang dengan wajar dan optimal pada seluruh aspek perkembangan. Aspek perkembangan tersebut meliputi kepribadian, kemampuan berbahasa, kognitif, fisik motorik, dan seni (Depdiknas, 2004).

Melihat tujuan tersebut, maka salah satu aspek yang dikembangkan di TK adalah Kognitif. Kognitif (daya pikir) merupakan potensi mental yang ada pada diri individu untuk menangkap, mengolah, menyimpan, dan mengungkap kembali pengetahuan. Tingkat kemampuan individu untuk memproses pengetahuan seperti itu dapat dinyatakan sebagai kecerdasan. Kecerdasan anak merupakan potensi penting dari keberhasilan belajar, bahkan sering menentukan keberhasilan hidup seseorang. Karena demikian halnya, maka upaya untuk meningkatkan kecerdasan individu cenderung dilakukan dengan sungguh-sungguh oleh pendidik.

Gardner (Lwin, dkk, 2005) menyebutkan kemampuan kognitif dengan istilah kecerdasan matematis logis. Kecerdasan ini merupakan kemampuan untuk menangani bilangan dan perhitungan, pola dan pemikiran logis dan ilmiah. Anak yang cerdas secara matematis sering tertarik dengan bilangan dan pola. Mereka menikmati berhitung dengan cepat untuk belajar menambah, mengurangi, mengalikan, dan membagi.

Pengembangan kognitif bertujuan untuk mengembangkan kemampuan pemikiran anak agar dapat mengolah pengetahuan perolehan belajaranya, serta menemukan bermacam alternatif pemecahan masalah, membantu anak mengembangkan kemampuan logika matematikanya dan pengetahuan akan ruang dan waktu, serta mempunyai kemampuan untuk memilah-milah, mengelompokkan serta mempersiapkan pengembangan kemampuan berpikir teliti (Depdiknas : 2004)

Untuk mencapai tujuan pendidikan tersebut selalu diadakan suatu pembaharuan. Pembaharuan tersebut meliputi pembaharuan kurikulum, peningkatan pembelajaran, dan efektivitas metode pembelajaran (Nurhadi 2003: 23). Pembaharuan kurikulum di Taman Kanak-Kanak terbukti adanya kurikulum 1994 disempurnakan menjadi kurikulum 2004. untuk meningkatkan kualitas pendidikan di Taman Kanak-Kanak dikembangkan melalui bidang pengembangan. Salah satu 
bidang pengembangan tersebut adalah bidang pengembangan kognitif. Bidang pengembangan ini bertujuan untuk mengembangkan kemampuan berfikir anak untuk mengolah perolehan belajaranya, dapat menemukan bermacam-macam alternative pemecahan masalah, dapat membantu anak mengembangkan kemampuan matematika dan pengetahuan akan ruang dan waktu, serta kemampuan untuk memilah-milah, mengelompokkan serta mempersiapkan pengembangan kemampuan berfikir teliti (Depdiknas, 2004).

Untuk mencapai tujuan tersebut meliputi beberapa komponen. Salah satu komponen yang penting adalah pendidik. Pendidik harus selalu meningkatkan profesionalisme dalam mengolah dan melaksanakan pembelajaran di Taman KanakKanak. Pendidik harus memahami secara mendalam karakteristik anak, strategi dan memfasilitasi perkembangan anak, mengukur tingkat perkembangan anak. Pemahaman tersebut dapat diaktualisasikan dalam merancang dan melaksanakan pembelajaran yang inovatif, aktif, efektif, demokratif, dan menyenangkan. Pembelajaran yang inovatif, aktif, efektif, demokratif, dan menyenangkan tercapai apabila pembelajaran tercipta dengan kreatifitas anak yang tinggi. Kreatifitas anak merupakan aspek yang penting dalam keberhasilan belajar anak.

Dari uraian di atas dapat disimpulkan bahwa kreatifitas anak sangat menentukan dalam mencapai suatu keberhasilan dalam pembelajaran. Kreatifitas harus dilaksanakan untuk mencapai semua tujuan pembelajaran. Namun pada kenyataannya belum semua pembelajaran di Taman Kanak-Kanak dapat mengutamakan adanya kreatifitas anak dalam proses pembelajaran.

Salah satunya di TK Al.Hidayah Ngadirejo Kec. Kepanjenkidul Kota Blitarmasih belum sesuai dengan harapan. Berdasarkan pengamatan dari guru bahwa pengembangan kognitif anak kurang maksimal. Hal ini terlihat pada pembelajaran kurang membuat kreatifitas anak berkembang. Guru masih kurang dalam penggunaan media pembelajaran, metode guru yang didominasi dengan metode ceramah. Sehingga pembelajaran kurang aktif, kreatif, efektif, dan menyenangkan. Hal ini tampak pada hasil belajar anak masih banyak yang belum mencapai ketuntasan. Ini tampak pada penilaian dari 15 anak ada 5 yang belum tuntas dalam pembelajaran bidang pengembangan kognitif dalam mengenal konsep bilangan. Dalam pembelajaran materi ini masih banyak anak yang ramai sendiri, tidak konsentrasi pada pembelajaran, bermain sendiri dan belum memahami materi setelah proses pembelajaran.

Berdasarkan permasalahan di atas peneliti dan juga sebagai guru berusaha meningkatkan proses pembelajaran pada bidang pengembangan kognitif dalam mengenal bilangan untuk lebih bermakna, aktif, kreatif, efektif dan membuat anak senang dalam belajar.

Agar pembelajaran tersebut tercapai guru dan juga sebagai peneliti melakukan berbagai macam metode pembelajaran. Salah satu metode yang digunakan untuk mencapai tujuan tersebut adalah metode pembelajaran kooperatif dengan Think Pair Share. Metode Think-Pair-Share dikembangkan oleh Frank Lyman dari Universitas Maryland. Metode ini memberikan kepada para anak waktu untuk berpikir dan merespon serta saling membantu satu sama lain. Adapun langkahlangkah metode Think-Pair-Share menurut Lyman dan Nurhadi (2004:67) adalah: (1) Berpikir (Thinking) yaitu guru mengajukan suatu permasalahan atau pertanyaan yang terkait dengan pelajaran dan anak diberi kesempatan beberapa saat untuk memikirkan secara individu mengenai jawaban yang berhubungan dengan pelajaran, (2) Berpasangan (Pairing) yaitu guru meminta kepada anak untuk berpasangan dan berdiskusi mengenai apa yang telah dipikirkan. Interaksi selama periode ini dapat menghasilkan jawaban bersama jika suatu pertanyaan telah diajukan atau penyampaian ide bersama jika suatu permasalahan telah diidentifikasi, (3) Berbagi (Sharing) yaitu guru meminta pasangan-pasangan tersebut untuk berbagi atau bekerja sama dengan kelas secara keseluruhan mengenai apa yang telah mereka bicarakan. Pada langkah ini akan menjadi efektif jika guru berkeliling kelas dari pasangan satu 
ke pasangan lain, sehingga sebagian dari pasangan atau seluruh pasangan dapat memperoleh kesempatan untuk melaporkan hasil diskusinya.

Dalam penerapannya untuk pembelajaran kooperatif dengan Think-PairShare yaitu mengenal konsep bilangan. Hal ini dapat dilaksanakan dengan tahapan: (1) Thinking (berpikir) dalam pembelajaran ini pada intinya siswa diberi suatu permasalahan tentang materi pemahaman konsep bilangan dalam wujud tugas secara individu dan anak diberi kesempatan untuk memecahkan secara individu, (2) Pairing (berpasangan) dalam tahap ini setelah anak diberi kesempatan untuk berpikir secara individu kemudian anak dibentuk kelompok berpasangan dengan teman satu bangku dan diberi kesempatan untuk membahas kembali masalahnya dengan kelompoknya. (3) Sharing (berbagi) dalam tahap ini tiap kelompok setelah menyelesaikan soal secara kelompok dilanjutkan dengan pembahasan. Setiap kelompok mengemukakan suatu permasalahan secara bergantian. Guru bertugas sebagai fasilitator dan mengarahkan serta membimbing anak dan bersama anak menyimpulkan hasil diskusi.

Dari uraian di atas dapat disimpulkan bahwa dengan metode pembelajaran kooperatif (Think-Pair-Share) yang dilaksanakan berdasarkan tahapan-tahapan berpikir secara individu, dan dilanjutkan dalam pemecahan dengan kelompok serta disimpulkan secara bersama-sama dalam kelompok kelas akan membuat pembelajaran bisa bermakna bagi anak dan guru. Dengan metode Think-Pair-Share diharapkan pembelajaran menyenangkan dan menjadikan anak lebih mudah memahami suatu konsep dari pelajaran yang dipelajari. Dengan pemahaman konsep dapat dapat menerapkan dan memecahkan suatu masalah dengan tepat dan cepat sesuai dengan harapan. Dengan metode ini dapat melatih kerja sama anak secara optimal dan dapat efektif, efisien dalam penyampaian materi dan waktu yang dipergunakan.

Oleh karena itu, perlu dilaksanakannya penelitian kelas sebagai upaya bahwa dengan penerapan pembelajaran kooperatif Think Pair Share dapat meningkatkan peningkatan kreatifitas dan hasil belajar anak dalam mengenal bilangan pada program pengembangan kognitif di Taman Kanak-Kanak Alhidayah Ngadirejo Kec. Kepanjenkidul Kota Blitar .

\section{METODE}

\section{Pendekatan dan Jenis Penelitian}

Dalam penelitian ini pendekatan yang digunakan adalah pendekatan kualitatif. Closswel dalam Wiriya Atmaja, Chrochiati (2006:08) menyatakan bahwa penelitian kualitatif adalah sebuah proses inkuiri yang menyelidiki masalah sosial dan kemanusiaan dengan metodologi yang berbeda. Dalam penelitian ini peneliti mendiskripsikan semua situasi dan kondisi yang terjadi pada pembelajaran. Peneliti menggunakan pendekatan-pendekatan ini karena sesuai untuk memecahkan permasalahan yang dikaji dalam penelitian ini.

Jenis pendekatan yang digunakan adalah Penelitian Tindakan Kelas. Penelitian ini merupakan salah satu cara guru agar dapat mengorganisasikan, kondisi pembelajaran, dan belajar dari pengalaman mereka sendiri. Guru dapat menerapkan gagasan perbaikan dalam pembelajaran.

\section{Subyek Penelitian}

Subyek penelitian adalah anak TK Alhidayah Ngadirejo Kec. Kepanjenkidul Kota. Blitar. Jumlah anak kelompok B ada 15 anak, terdiri dari 8 anak laki-laki dan 7 anak perempuan.

\section{Lokasi dan Waktu Penelitian}

Penelitian ini dilaksanakan di TK Alhidayah Ngadirejo Kec. Kepanjenkidul Kota Blitar semester II tahun 2016/2017. Waktu penelitian dilakukan pada semester II tahun 2016/2017 pada bulan Februari sampai dengan bulan April 2017. Penentuan waktu mengacu pada kalender akademik sekolah. 


\section{Data dan Sumber Data}

Data yang diperlukan dalam penelitian ini meliputi data hasil belajar anak yang berupa produk dan proses pembelajaran. Secara terperinci perolehan data dijelaskan sebagai berikut: (1) Data hasil belajar berupa produk, yaitu pemahaman konsep bilangan diperoleh dari skor tes pada akhir kegiatan pembelajaran. (2) Data kreatifitas anak diperoleh dari rubrik penilaian atau lembar pengamatan dari observasi meliputi, keaktifan bertanya, kerja sama, ketepatan dalam menjawab dan tanggung jawab. Sumber data dalam penelitian ini adalah anak TK Alhidayah Ngadirejo Kec. Kepanjenkidul Kota Blitar dan peneliti. Peneliti bertindak sebagai pelaksana tindakan. Sedangkan mitra peneliti sebagai observer tindakan yaitu teman sejawat.

\section{Teknik Pengumpulan Data}

Teknik pengumpulan data dalam penelitian ini adalah tes, observasi, dan diskusi dengan teman sejawat. Tes dipergunakan untuk mendapatkan data tentang hasil belajar anak. Observasi digunakan untuk menyimpulkan data tentang kreatifitas anak dalam proses pembelajaran dan implementasi pembelajaran kooperatif. Diskusi dan wawancara antara guru dan teman sejawat untuk refleksi hasil siklus penelitian tindakan kelas.

\section{Analisis Data}

Analisis data dilakukan setelah pemberian tindakan pada masing-masing siklus yang telah dilakukan. Analisis data merupakan proses menyeleksi, menyederhanakan, memfokuskan, mengabstrakkan, dan mengorganisasi data secara sistematis dan rasional untuk menyusun jawaban terhadap tujuan penelitian. Teknik analisa data yang digunakan dalam penelitian ini adalah teknik analisa data dan pemberian kesimpulan. Selain itu juga direngkapi dari hasil catatan lapangan dan observasi anak.

\section{Keberhasilan Anak}

Dalam menganalisa tingkat keberhasilan anak ditentukan denga kriteria, ketuntasan yang meliputi ketuntasan individu dan ketuntasan klasikal. Ketuntasan belajar secara klasikal apabila anak dalam belajar mencapai $75 \%$ dari jumlah anak mengalami ketuntasan. Sedangkan ketuntasan individu apabila anak dalam belajar mendapat bintang 3 atau anak sudah mampu memecahkan permasalahan dalam belajar. Kurang dari ketuntasan tersebut anak belum dikatakan mengalami ketuntasan.

Secara teknis, keberhasilan belajar diperoleh dari hasil evaluasi individu dan kelompok yang dilaksanakan tiap siklus. Jumlah soal individu setiap siklus, 5 item soal. Pemberian penilaian dilakukan dengan cara betul 1 sampai 2 mendapat $\hbar$, betul

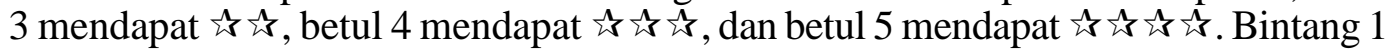
apabila anak masih belum mampu, bintang 2 anak mampu dengan bimbingan, bintang 3 anak mampu tanpa bimbingan, dan bintang 4 anak sangat mampu.

Dari hasil yang diperoleh anak selanjutnya diprosentase untuk menentukan ketuntasan secara individu dan ketuntasan klasikal. Apabila memperoleh $75 \%$ atau lebih dari jumlah anak yang mengalami ketuntasan, maka dikatakan ketuntasan klasikal berhasil, dan sebaliknya apabila masih dibawah $75 \%$ anak yang belum tuntas, maka ketuntasan klasikal dikatakan belum tercapai. Untuk ketuntasan individu apabila anak sudah mencapai nilai bintang 3, maka anak dapat dikatakan berhasil atau tuntas.

Anak yang belum mencapai ketuntasan baik individu maupun klasikal perlu adanya upaya peningkatan dengan mengadakan remedial, pemberian bimbingan khusus dan pelaksanaan pada siklus berikutnya. Bagi anak yang sudah mencapai ketuntasan maka perlu diberikan pengayaan. 


\section{Kreatifitas Anak}

Kreatifitas anak diambil dari hasil pengamatan melalui lembar pengamatan. Kreatifitas anak meliputi aspek keaktifan anak dalam bertanya, kemampuan bekerjasama, ketepatan dalam menjawab, dan bertanggungjawab. Tiap aspek diberi skor maksimal 4 dan skor minimal 1. Adapun kriteria dari tiap skor (terlampir pada lembar pengamatan kreatifitas anak). Jadi dari keempat skor maksimal 16 atau $100 \%$. Anak mencapai ketuntasan apabila mendapat minimal $75 \%$ atau skor 12 dari keemapt aspek tersebut.

\section{Prosedur Penelitian}

Penelitian tindakan kelas ini dilaksanakan dengan tahapan siklus. masingmasing siklus terdiri dari 4 tahapan, yaitu: (1) perencanaan (planning), (2) pelaksanaan (acting), (3) pengamatan (observing), (4) refleksi (reflecting). Keempat bagian ini merupakan suatu rangkaian yang berulang sampai mencapai hasil yang diharapkan. 1997:84).

Berikut ini model PTK Kemmis dan Taggart (dalam Suharsimi Arikunto,

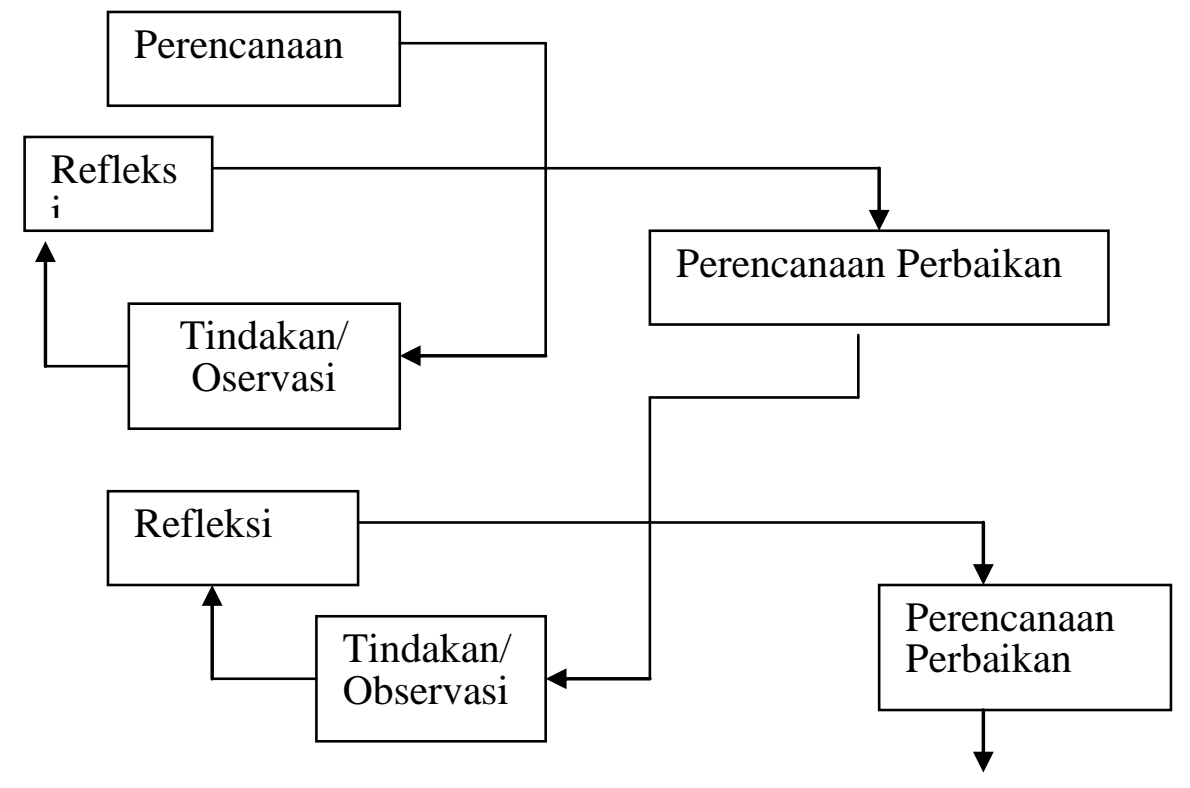

\section{Gambar 1 PTK Model Kemmis dan Taggart}

Siklus I

Adapaun langkah-langkah kerja selama penelitian adalah sebagai berikut:

Perencanaan (planning). Pada tahap ini peneliti melakukan analisis kurikulum, membuat Rencana Pembelajaran dengan metode kooperatif Think Pair Share. Peneliti dan juga guru membuat RPP dengan materi bidang pengembangan kognitif dalam mengenal konsep bilangan. Langkah berikutnya guru membuat lembar kerja untuk anak baik lembar individu dan kelompok, membuat lembar pengamatan untuk anak dan guru, dan dilanjutkan membuat lembar penilaian serta menyiapkan alat peraga yang akan dipergunakan dalam pelaksanaan pembelajaran.

Pelaksanaan tindakan pada penelitian ini mencakup kegiatan pembelajaran yang dilaksanakan oleh guru dan anak dengan metode pembelajaran kooperatif Think Pair Share. 
Observasi. Pada tahap ini peneliti dibantu teman sejawat melakukan observasi. Observasi dilakukan pada saat pelaksanaan pembelajaran berlangsung. Kolaborator bertugas untuk mengamati semua yang terjadi dalam pembelajaran dengan panduan instrument yang telah tersedia. Semua hasil pengamatan dicatat dan dipergunakan sebagai acuan pada tahap berikutnya. Observasi ditujukan pada proses pembelajaran. Kreatifitas anak yang meliputi keaktifan anak dalam bertanya, kerjasama, ketepatan dalam menjawab pertanyaan dan bertanggung jawab serta hasil belajar dan juga guru terhadap proses pembelajaran.

Refleksi. Pada akhir siklus ini diadakan refleksi terhadap hasil yang diperoleh selama pengamatan pada waktu pelaksanaan pembelajaran. Pada kegiatan refleksi ini dapat diketahui permasalahan yang muncul pada siklus I, sehingga peneliti dapat melakukan perbaikan pada siklus berikutnya.

\section{Siklus II}

Seperti halnya siklus I, siklus II juga terdiri dari perencanaan (planning), pelaksanaan (acting), pengamatan (observing), dan refleksi (reflecting). Pada tahap perencanaan siklus II ini peneliti mempersiapkan RPP dengan metode kooperatif Think Pair Share, berdasarkan hasil refleksi siklus I. Pelaksanaan tindakan ini dilakukan berdasarkan pada rencana pembelajaran kooperatif Think Pair Share dari hasil refleksi siklus I.Pada tahap pengamatan peneliti dan kolaborator mengamati dan mencatat semua yang terjadi pada pembelajaran yang dilaksanakan dengan bantuan lembar observasi dan lembar pengamatan yang tersedia. Peneliti dan kolaborator melakukan refleksi terhadap pelaksanaan siklus II dan menganalisa untuk serta membuat kesimpulan atau pelaksanaan pembelajaran kooperatif Think Pair Share dalam meningkatkan kreatifitas anak dan hasil belajar anak dalam pembelajaran pengenalan konsep bilangan di Taman Kanak-Kanak.

\section{HASIL}

SIklus I

\section{Keberhasilan Anak}

Berdasarkan pelaksanaan pembelajaran Think Pair Share pada materi pengenalan bilangan pada anak TK Alhidayah Ngadirejo Kecamatan Kepanjenkidul Kota Blitar diperoleh data nilai sebagai berikut:

Tabel 1 Nilai Hasil Evaluasi Siklus I

\begin{tabular}{|c|c|c|c|c|c|}
\hline \multirow{2}{*}{ No. } & \multirow{2}{*}{ Nama Anak } & \multirow{2}{*}{ Nilai } & \multirow{2}{*}{ Ketercapaian } & \multicolumn{2}{|c|}{ Ketuntasan } \\
\hline & & & & $\mathbf{Y a}$ & Tidak \\
\hline 1. & Fikan & $\vec{\Delta} \vec{k}$ & $75 \%$ & $\sqrt{ }$ & \\
\hline 2. & Safira & $\vec{\Delta} \vec{k}$ & $75 \%$ & $\checkmark$ & \\
\hline 3. & Vina & $\dot{t} t \vec{t} t$ & $75 \%$ & $\sqrt{ }$ & \\
\hline 4. & Amilta & $\vec{k} \boldsymbol{\lambda}$ & $50 \%$ & & $\checkmark$ \\
\hline 5. & Mirza & $\dot{\Delta}$ & $50 \%$ & & $\checkmark$ \\
\hline 6. & Fafa & 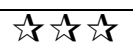 & $75 \%$ & $\checkmark$ & \\
\hline 7. & Luthfi & 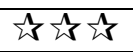 & $75 \%$ & $\checkmark$ & \\
\hline 8. & Rahma & $\dot{\Delta} \vec{\Delta}$ & $50 \%$ & & $\checkmark$ \\
\hline 9. & Galang & $\vec{t}$ & $25 \%$ & & $\checkmark$ \\
\hline 10. & Cua & $\dot{\Delta} \vec{\Delta}$ & $75 \%$ & $\checkmark$ & \\
\hline 11. & Okky & $\vec{\lambda}$ & $50 \%$ & & $\checkmark$ \\
\hline 12. & Radincaa & 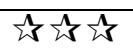 & $75 \%$ & $\checkmark$ & \\
\hline 13. & Rafi & 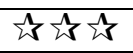 & $75 \%$ & $\sqrt{ }$ & \\
\hline 14. & Resya & $\vec{\omega}$ & $50 \%$ & & $\checkmark$ \\
\hline 15. & Wanda & $\vec{i} \dot{2}$ & $50 \%$ & & $\checkmark$ \\
\hline & Rata-rata & & $62 \%$ & & ntas \\
\hline
\end{tabular}


Dari tabel perolehan nilai di atas diperoleh bahwa pada pembelajaran siklus I dapat disimpulkan bahwa perlu adanya perbaikan bagi anak yang belum mencapai ketuntasan yaitu sebanyak 7 anak dan perlu adanya perbaikan dan bimbingan khusus sampai mencapai ketuntasan yang telah ditetapkan. Dan bagi anak yang sudah mencapai ketuntasan perlu diberikan adanya pengayaan dengan diberikan soal lagi dan diusahakan agar tetap mempertahankan dan meningkatkan prestasi yang diraih.

\section{Kreativitas Anak}

Dari hasil observasi kreatifitas anak yang meliputi keaktifan dalam bertanya, kemampuan bekerjasama, ketepatan dalam menjawab, dan tanggung jawab dalam mengerjakan tugas. Secara keseluruhan pada siklus I ini tentang kreatifitas anak masih kurang memuaskan. Dilihat dari keempat keterampilan tersebut dalam pembelajaran masih tampak 4 anak yang sempat berkelahi untuk berebut peraga, tampak beberapa anak belum selesai mengerjakan tugas tepat waktu karena tidak dapat memecahkan permasalahan atau tugas. Ada 5 anak yang sempat diam saat ada tugas meskipun guru membimbingnya. Kreatifitas anak dapat dilihat dari hasil observasi yang meliputi aspek keaktifan bertanya, kemampuan bekerjasama, ketepatan menjawab, dan tanggung jawab sebagai berikut:

Tabel 2 Hasil Observasi Kreatifitas Anak Siklus I

\begin{tabular}{|c|c|c|c|c|c|c|c|c|}
\hline \multirow{2}{*}{ No } & \multirow{2}{*}{$\begin{array}{c}\text { Nama } \\
\text { Anak }\end{array}$} & $\begin{array}{c}\text { Keakti } \\
\text { fan } \\
\text { Bertan } \\
\text { ya }\end{array}$ & $\begin{array}{c}\text { Beke } \\
\text { rja- } \\
\text { sama }\end{array}$ & $\begin{array}{c}\text { Ketepat } \\
\text { an } \\
\text { Menja } \\
\text { wab }\end{array}$ & $\begin{array}{c}\text { Tangg } \\
\text { ung } \\
\text { Jawab }\end{array}$ & $\begin{array}{c}\text { Jumla } \\
\text { h } \\
\text { Skor }\end{array}$ & $\begin{array}{c}\text { Pers } \\
\text { en } \\
(\boldsymbol{\%})\end{array}$ & $\begin{array}{c}\text { Ketunt } \\
\text { as-an }\end{array}$ \\
\hline 1. & Fikan & 2 & 3 & 3 & 3 & 11 & 69 & Tidak \\
\hline 2. & Safira & 3 & 3 & 3 & 3 & 12 & 75 & Tuntas \\
\hline 3. & Vina & 3 & 3 & 3 & 2 & 11 & 69 & Tidak \\
\hline 4. & Amilta & 2 & 2 & 2 & 2 & 8 & 50 & Tidak \\
\hline 5. & Mirza & 2 & 2 & 3 & 2 & 9 & 56 & Tidak \\
\hline 6. & Fafa & 3 & 2 & 3 & 3 & 11 & 69 & Tidak \\
\hline 7. & Luthfi & 3 & 2 & 3 & 3 & 11 & 69 & Tidak \\
\hline 8. & Rahma & 2 & 2 & 3 & 2 & 9 & 56 & Tidak \\
\hline 9. & Galang & 2 & 2 & 2 & 2 & 8 & 50 & Tidak \\
\hline 10. & Cua & 3 & 3 & 2 & 3 & 11 & 69 & Tidak \\
\hline 11. & Okky & 3 & 3 & 3 & 2 & 11 & 69 & Tidak \\
\hline 12. & Radincaa & 2 & 2 & 2 & 2 & 8 & 50 & Tidak \\
\hline 13. & Rafi & 3 & 3 & 3 & 3 & 12 & 75 & Tuntas \\
\hline 14. & Resya & 3 & 3 & 3 & 3 & 12 & 75 & Tuntas \\
\hline 15. & Wanda & 2 & 2 & 2 & 2 & 8 & 50 & Tidak \\
\hline & Rata-rata & $\mathbf{2 , 5}$ & $\mathbf{2 , 5}$ & $\mathbf{2 , 7}$ & $\mathbf{2 , 5}$ & $\mathbf{1 0}$ & $\mathbf{6 3}$ & Tidak \\
\hline
\end{tabular}

Catatan: skor maksimal tiap-tiap aspek adalah 4. Jumlah maksimal keempat aspek adalah 16. Tingkat kreatifitas anak dikatakan berhasil apabila nilai hasil pengamatan dari tiap-tiap aspek minimal 3 dan maksimal 4 (minimal 75\% dari skor maksimal).

Dari tabel tersebut diperoleh bahwa perlu adanya peningkatan dalam melatih anak untuk aktif dan kreatif dalam mengikuti pembelajaran khususnya keterampilan untuk bertanya pada teman dan guru apabila terjadi kesulitan dalam belajar. Khususnya pada anak yang belum tuntas dalam aspek ini. Dalam hal ini tampak 7 anak yang belum tuntas. Anak-anak tersebut perlu dan harus diberikan motivasi dan bimbingan dalam melatih dirinya untuk aktif dan tidak takut untuk bertanya pada 
teman atau guru apabila mengalami kesulitan dalam belajar. Dan dapat disimpulkan bahwa secara khasiat masih belum tuntas dalam hal kreatifitas anak dalam aspek bertanya.

Dalam aspek kerjasama masih belum mencapai ketuntasan. Hal ini ditunjukkan baik secara perorangan atau kelompok masih dibawah standar yang ditentukan oleh sekolah tersebut. Hal ini perlu adanya perhatian khusus bagi anakanak yang belum menscapai ketuntasan dalam aspek kerjasama dalam kelompok baik kelompok kecil maupun kelompok besar di kelas.

Pada aspek ketepatan menjawab pada siklus I ini masih belum mencapai ketuntasan baik secara perorangan dan klasikal, karena masih dibawah standar ketuntasan yang di tetapkan. Dari perolehan pada aspek rasa tanggung jawab pada siklus satu belum mencapai ketuntasan baik secara perorangan atau klasikal.

\section{Siklus II}

\section{Keberhasilan Anak}

Berdasarkan pelaksanaan pembelajaran Think Pair Share pada materi pengenalan bilangan pada anak TK Alhidayah Ngadirejo Kec. Kepanjenkidul. pada siklus II ini diperoleh data nilai sebagai berikut:

Tabel 3 Nilai Hasil Evaluasi Siklus II

\begin{tabular}{|c|c|c|c|c|c|}
\hline \multirow{2}{*}{ No. } & \multirow{2}{*}{ Nama Anak } & \multirow{2}{*}{ Nilai } & \multirow{2}{*}{ Ketercapaian } & \multicolumn{2}{|c|}{ Ketuntasan } \\
\hline & & & & Ya & Tidak \\
\hline 1. & Fikan & $\vec{\Delta} \dot{\Delta} \vec{\Delta} \dot{\Delta}$ & $100 \%$ & $\checkmark$ & \\
\hline 2. & Safira & 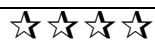 & $100 \%$ & $\checkmark$ & \\
\hline 3. & Vina & 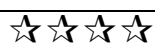 & $100 \%$ & $\checkmark$ & \\
\hline 4. & Amilta & 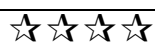 & $100 \%$ & $\checkmark$ & \\
\hline 5. & Mirza & 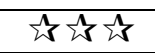 & $75 \%$ & $\checkmark$ & \\
\hline 6. & Fafa & $\dot{\Delta} \hat{t} t$ & $75 \%$ & $\checkmark$ & \\
\hline 7. & Luthfi & $\vec{\Delta} \dot{\Delta} \vec{\Delta}$ & $75 \%$ & $\checkmark$ & \\
\hline 8. & Rahma & $\dot{\Delta} \vec{\Delta} \dot{\Delta}$ & $75 \%$ & $\checkmark$ & \\
\hline 9. & Galang & $\vec{t} \hat{s}$ & $50 \%$ & & $\checkmark$ \\
\hline 10. & Cua & 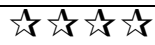 & $100 \%$ & $\checkmark$ & \\
\hline 11. & Okky & $\vec{\Delta} \hat{厶}$ & $75 \%$ & $\checkmark$ & \\
\hline 12. & Radincaa & $\vec{\Delta} \vec{\Delta} \dot{\Delta}$ & $100 \%$ & $\checkmark$ & \\
\hline 13. & Rafi & 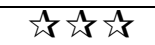 & $75 \%$ & $\checkmark$ & \\
\hline 14. & Resya & 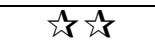 & $50 \%$ & & $\checkmark$ \\
\hline 15. & Wanda & $\vec{\Delta} \hat{\Delta} \vec{k}$ & $75 \%$ & $\checkmark$ & \\
\hline & Rata-rata & & $82 \%$ & & ntas \\
\hline
\end{tabular}

Dari tabel tersebut diperoleh bahwa terjadi peningkatan ketuntasan hasil belajar anak dari 8 anak menjadi 13 anak. Dan bagi anak yang sudah mencapai ketuntasan perlu diberikan adanya pengayaan dengan diberikan soal lagi dan diusahakan agar tetap mempertahankan serta meningkatkan prestasi yang diraih.

\section{Kreatifitas Anak}

Dari hasil observasi kreatifitas anak yang meliputi keaktifan dalam bertanya, kemampuan bekerjasama, ketepatan dalam menjawab, dan tanggung jawab dalam mengerjakan tugas. Secara keseluruhan pada siklus II ini tentang kreatifitas anak mendapat hasil yang memuaskan. Dilihat dari keempat keterampilan tersebut dalam pembelajaran tampak ada peningkatan. Tampak 6 anak yang mengerjakan dengan tepat dan cepat, dapat berdiskusi dengan teman sebangkunya dengan baik dan dapat mengungkapkan serta melaporkan hasil kerjanya dengan baik dan benar. Anak yang lain dapat mengerjakan tepat waktu dan adanya peningkatan hasil dan pemahaman konsep terhadap bilangan. Kreatifitas anak dapat dilihat dari hasil observasi yang 
meliputi aspek keaktifan bertanya, kemampuan bekerjasama, ketepatan menjawab, dan tanggung jawab sebagai berikut:

Tabel 4 Hasil Observasi Kreatifitas Anak Siklus II

\begin{tabular}{|c|l|c|c|c|c|c|c|c|}
\hline \multirow{2}{*}{ No } & \multirow{2}{*}{$\begin{array}{c}\text { Nama } \\
\text { Anak }\end{array}$} & $\begin{array}{c}\text { Keaktif } \\
\text { an } \\
\text { Bertan } \\
\text { ya }\end{array}$ & $\begin{array}{c}\text { Beker } \\
\text { ja- } \\
\text { sama }\end{array}$ & $\begin{array}{c}\text { Ketepat } \\
\text { an } \\
\text { Menjaw } \\
\text { ab }\end{array}$ & $\begin{array}{c}\text { Tangg } \\
\text { ung } \\
\text { Jawab }\end{array}$ & $\begin{array}{c}\text { Jumla } \\
\text { h Skor }\end{array}$ & $\begin{array}{c}\text { Persen } \\
(\%)\end{array}$ & $\begin{array}{c}\text { Ketunta } \\
\text { s-an }\end{array}$ \\
\hline 1. & Fikan & 4 & 3 & 4 & 4 & 15 & 94 & Tuntas \\
\hline 2. & Safira & 4 & 3 & 3 & 4 & 14 & 88 & Tuntas \\
\hline 3. & Vina & 4 & 3 & 4 & 4 & 15 & 94 & Tuntas \\
\hline 4. & Amilta & 4 & 4 & 3 & 4 & 15 & 94 & Tuntas \\
\hline 5. & Mirza & 3 & 4 & 3 & 4 & 14 & 88 & Tuntas \\
\hline 6. & Fafa & 3 & 4 & 3 & 4 & 14 & 88 & Tuntas \\
\hline 7. & Luthfi & 4 & 4 & 3 & 4 & 15 & 94 & Tuntas \\
\hline 8. & Rahma & 3 & 4 & 4 & 4 & 15 & 94 & Tuntas \\
\hline 9. & Galang & 3 & 3 & 3 & 3 & 12 & 75 & Tuntas \\
\hline 10. & Cua & 3 & 4 & 4 & 3 & 14 & 88 & Tuntas \\
\hline 11. & Okky & 4 & 4 & 3 & 4 & 15 & 94 & Tuntas \\
\hline 12. & Radincaa & 3 & 4 & 3 & 4 & 14 & 88 & Tuntas \\
\hline 13. & Rafi & 3 & 4 & 4 & 3 & 14 & 88 & Tuntas \\
\hline 14. & Resya & 4 & 3 & 4 & 3 & 14 & 88 & Tuntas \\
\hline 15. & Wanda & 4 & 3 & 4 & 4 & 15 & 94 & Tuntas \\
\hline & Rata-rata & $\mathbf{3 , 5}$ & $\mathbf{3 , 6}$ & $\mathbf{3 , 4}$ & $\mathbf{3 , 7}$ & $\mathbf{1 4 , 2}$ & $\mathbf{9}$ & Tuntas \\
\hline
\end{tabular}

Dari tebel tersebut nampak adanya peningkatan dalam melatih anak untuk aktif dan kreatif dalam mengikuti pembelajaran khususnya keterampilan untuk bertanya pada teman dan guru apabila terjadi kesulitan dalam belajar. Khususnya pada anak yang belum tuntas dalam aspek ini. Dalam hal ini tampak 15 anak yang tuntas. Anak-anak tersebut perlu dan harus diberikan motivasi dan tugas berikutnya untuk mengembangkan keterampilan yang telah dimiliki. Dan dapat disimpulkan bahwa secara klasikal sudah tuntas dalam hal kreatifitas anak dalam aspek bertanya.

Pada siklus ini dalam aspek kerja sama sudah mencapai ketuntasan. Hal ini ditunjukkan baik secara perorangan atau kelompok sudah memenuhi standar yang ditentukan oleh sekolah tersebut. Hal ini perlu adanya pengayaan bagi anak-anak yang sudah mencapai ketuntasan dalam aspek kerja sama dengan kelompok baik kelompok kecil maupun kelompok besar di kelas. Dari perolehan kelima hal di atas pada siklus II mencapai ketuntasan baik secara perorangan maupun klasikal.

\section{PEMBAHASAN}

Dari hasil pengamatan mulai siklus I sampai siklus II hasil belajar yang diinginkan mengalami peningkatan. Uraian dari peningkatan hasil belajar anak setelah melaksanakan pembelajaran kooperatif model Think Pair Share adalah:

Tabel 5 Hasil Belajar dan Kreatifitas Anak

\begin{tabular}{|c|c|c|c|c|c|}
\hline \multirow{2}{*}{$\mathbf{N}$} & \multirow[b]{2}{*}{ Aspek } & \multicolumn{2}{|c|}{ Prosentase } & \multirow[b]{2}{*}{ Ketuntasan } & \multirow[b]{2}{*}{ Keterangan } \\
\hline & & Siklus I & $\begin{array}{c}\text { Siklus } \\
\text { II }\end{array}$ & & \\
\hline 1 & Hasil Belajar & $53,3 \%$ & $86,6 \%$ & $75 \%$ & Meningkat \\
\hline 2 & Keaktifan Bertanya & $55 \%$ & $100 \%$ & $75 \%$ & Meningkat \\
\hline 3 & Keaktifan & $46,6 \%$ & $100 \%$ & $75 \%$ & Meningkat \\
\hline
\end{tabular}




\begin{tabular}{|c|l|c|c|c|c|}
\hline & Bekerjasama & & & & \\
\hline 4 & Ketepatan Menjawab & $67 \%$ & $100 \%$ & $75 \%$ & Meningkat \\
\hline 5 & Tanggung Jawab & $47 \%$ & $100 \%$ & $75 \%$ & Meningkat \\
\hline
\end{tabular}

\section{Hasil Belajar (Keberhasilan Anak)}

Hasil belajar diperoleh dari kegiatan melalui metode kooperatif Think Pair Share. Dalam pembelajaran ini anak memahami materi bidang pengembangan kognitif dalam mengenal bilangan secara berpikir sendiri, berdiskusi secara berpasangan dan berkelompok besar di kelas. Anak belajar berbagai pengalaman bertukar pendapat dan kerja sama dengan bimbingan guru. Pada siklus I masih banyak anak belum mencapai ketuntasan sesuai yang ditetapkan yaitu $75 \%$. Keberhasilan belajar dapat dilihat dari nilai anak, baik secara individu maupun klasikal. Hasil belajar pada pemahaman materi pada siklus I terdapat 53,33\%. Hal ini berarti belum mencapai ketuntasan yang ditetapkan yaitu $75 \%$. Pada siklus I ini keberhasilan belajar terdapat 8 anak yang tuntas dan 7 anak belum tuntas. Untuk mencapai ketuntasan hasil belajar, maka diadakan perbaikan pada siklus II.

Berdasarkan perolehan hasil belajar pada siklus I maka peneliti dan juga sebagai guru berusaha memperbaiki pada siklus II. Pada pelaksanaan siklus berusaha untuk memperbaiki hasil belajar pada siklus I. Pembelajaran pada siklus II juga melaksanakan pembelajaran kooperatif pada materi pengenalan konsep bilangan. Anak lebih diperhatikan terutama bagi anak yang kurang dapat memahami konsep bilangan. Anak diberikan bimbingan baik secara individu ataupun secara klasikal. Berdasarkan hasil observasi pada siklus II ini mengalami peningkatan yang cukup memuaskan. Pada siklus I prosentase hasil belajar secara klasikal mencapai 53,3\% dan pada siklus II mencapai 86,6\%. Ini berarti ada 13 anak yang tuntas dan 2 anak yang belum tuntas. Bagi siswa yang mencapai ketuntasan selalu diberikan bimbingan secara individual. Sehingga dapat dikatakan bahwa pembelajaran kooperatif Think Pair Share baik diterapkan untuk meningkatkan hasil belajar.

\section{Kreatifitas Anak}

\section{Kreatifitas dalam Bertanya}

Kreatifitas dalam bertanya pada anak dapat diperoleh selama proses pembelajaran yaitu adanya tukar pendapat dengan teman ketika berdiskusi dan pada waktu diskusi kelas. Pada siklus I banyak anak yang belum bisa berkomunikasi dengan teman dan takut bertanya balik dengan teman ataupun dengan gurunya. Banyak anak yang tidak dapat mengerjakan tugasnya karena takut bertanya pada waktu berdiskusi dengan temannya dan kelompok kelas. Banyak anak yang takut untuk bertanya pada guru pada waktu mengalami kesulitan, hal ini dijadikan pembelajaran pasif. Berdasarkan hasil observasi untuk aspek keaktifan bertanya pada siklus I mencapai 53\%. Pada siklus I ini masih perlu peningkatan. Untuk meningkatkan kreatifitas bertanya peneliti dan juga sebagai guru berusaha mengadakan perbaikan pada siklus II dengan materi yang sama dan metode yang sama yaitu Kooperatif Think Pair Share.

Berdasarkan hasil dari siklus I untuk meningkatkan kreatifitas bertanya, guru lebih memperhatikan pembelajaran untuk memotivasi anak untuk lebih aktif dalam belajar. Guru lebih banyak mempergunakan alat peraga untuk membangkitkan minat anak dalam belajar, dan memotivasi siswa untuk bertanya baik pada teman sebangkunya maupun dengan gurunya. Pada siklus II ini diperoleh prosentase $100 \%$. Dari hasil observasi ini dapat dikatakan bahwa pada siklus II mengalami peningkatan yang cukup memuaskan.

\section{Aspek Kerjasama}

Dalam pembelajaran kooperatif mengutamakan adanya kreatifitas anak dalam mengerjakan atau memecahkan masalah dengan bekerjasama atau keterampilan bekerjasama dan tanggung jawab dalam memecahkan masalah. Dengan kooperatif diharapkan siswa dapat terampil dan aktif dalam memecahkan suatu 
masalah dengan banyak pertimbangan dan musyawarah dengan lingkungannya. Aspek kerjasama pada pembelajaran dapat diperoleh melalui pembelajaran kooperatif Think Pair Share. Hal ini dapat dilihat pada anak yang mengerjakan soal dengan berfikir bersama sama dengan teman sebangku, dan dilanjutkan dengan musyawarah atau diskusi kelas. Dari kegiatan ini anak dituntut untuk lebih kreatif dalam belajar. Dari hasil observasi dari siklus I dengan siklus II terdapat peningkatan yang cukup memuaskan. Siklus I aspek kerjasama mencapai ketuntasan 46,6\% dan pada siklus II mencapai 100\% dari 24 anak. Pada siklus I anak belum dapat berperan dengan aktif dalam kerja kelompok baik secara berpasangan maupun dengan kelompok kelas. Ini disebabkan anak belum terbiasa dan guru kurang memberikan bimbingan baik secara individu ataupun kelompok. Berdasar permasalahan pada siklus I tersebut, maka guru berusaha memperbaikinya pada siklus II dengan memberikan bimbingan dan arahan pada anak akan pentingnya bekerjasama dengan memberikan motivasi dan rangsangan permasalahan pembelajaran mengenal bilangan dengan memasangkan gambar dan angka pada temannya yang sesuai. Dengan usaha ini terdapat adanya peningkatan pada aspek kerjasama pada siklus II mencapai $100 \%$. Sehingga dapat dikatakan dengan metode kooperatif dapat meningkatkan kreatifitas anak dalam bekerjasama dalam belajar.

\section{Ketepatan Menjawab}

Aspek ketepatan menjawab pertanyaan pada siklus I mencapai $67 \%$. Hal ini disebabkan adanya anak belum memahami materi dan belum memahami cara belajar dengan metode kooperatif Think Pair Share. Guru juga belum terbiasa menggunakan metode ini. Denga hasil yang diperoleh, maka pada siklus II diadakan perbaikan dengan menggunakan alat peraga gambar, angka, dan benda-benda asli di kelas untuk mengenal bilangan. Dengan usaha ini pada siklus II mencapai hasil 100\% dari jumlah anak 15. Dari hasil ini dapat dikatakan dengan metode Think Pair Share dapat meningkatkan ketepatan memecahkan masalah dalam pembelajaran.

\section{Aspek Rasa Tanggung Jawab}

Dalam pembelajaran di siklus I anak berdasarkan hasil observasi mencapai 47\%. Ini disebabkan adanya anak masih belum dapat melaksanakan pembelajaran yang maksimal, siswa masih banyak yang tidak dapat menyelesaikan soal pada waktunya. Guru belum dapat melakukan pembelajaran sesuai rencana pembelajaran yang direncanakan. Pada siklus II diusahakan agar anak dapat melaksanakan pembelajaran sesuai dengan perencanaan, dan tepat waktu. Untuk ini pada siklus II diadakan perbaikan dengan memberikan perhatian secara khusus pada anak, terutama pada anak yang kurang. Pemberian bimbingan secara klasikal dan individu. Guru lebih meningkatkan keterampilan menggunakan metode yang direncanakan. Guru memberikan lembar pertanyaan atau soal pada siswa secara individu dan kelompok dengan memberikan lembar soal jelas dengan memberikan gambar-gambar. Dengan usaha ini pada siklus II mencapai peningkatan menjadi 100\%. Dengan ini dapat dikatakan dengan metode kooperatif Think Pair Share dapat meningkatkan rasa tanggung jawab anak.

\section{KESIMPULAN}

Berdasarkan hasil penelitian tindakan kelas ini dapat disimpulkan sebagai berikut; (1) Penerapan pembelajaran dengan model Think Pair Share dapat meningkatkan hasil belajar konsep bilangan. Hal ini terbukti adanya peningkatan hasil belajar baik secara individu maupun kelompok. (2) Dari hasil observasi menunjukkan dengan metode kooperatif Think Pair Share dapat meningkatkan kreatifitas anak yang meliputi kreatifitas dalam bertanya, bekerjasama, menjawab pertanyaan, dan rasa tanggung jawab.

\section{SARAN}


Bagi guru, guru hendaknya dapat menggunakan metode kooperatif model Think Pair Share dalam mengajarkan konsep bilangan. Guru mau dan mampu melaksanakan kegiatan pendidikan, meneliti permasalahan dan memecahkan permasalahan pendidikan yang dialami dengan cara PTK (Penelitian Tindakan Kelas). Bagi sekolah, sekolah perlu memantau kegiatan di sekolah, menciptakan lingkungan belajar yang kondusif. Bekerja keras untuk meningkatkan mutu pendidikan secara kreatif dan inovatif. Bagi peneliti lain, Peneliti hendaknya menggunakan metode pembelajaran kooperatif Think Pair Share untuk meningkatkan kreatifitas dan hasil belajar pada materi pembelajaran yang lain.

\section{DAFTAR RUJUKAN}

Arikunto, Suharsimi. 1997. Prosedur Penilian Suatu Pendekatan Praktek. Jakarta : Rineka Cipta.

Asma, Nur. 2005. Model Pembelajaran Kooperatif. Jakarta : Depdikbud Dirjen Dikti.

Dasna, Wayan. 2007. Penelitian Tindakan Kelas dan Karya Ilmiah. Malang : Pusat Penelitian Pendidikan UM.

Depdiknas. 2004. Kurikulum 2004 Standar Kompetensi TK dan RA. Jakarta : Balitbang Depdiknas.

Dimyati dan Mudjiono. 1994. Belajar dan Pembelajaran. Jakarta : Dikti Depdikbud.

Lei, Anita. 2005. Cooperative Learning. Jakarta : Grasindo.

Lwin, May, dkk. 2005. Cara Pengembangan Berbagai Kecerdasan. Jakarta : PT Indeks.

Mei, Sondang. 2004. Pembelajaran Kooperatif. Surabaya : Dinas Pendidikan dan Kebudayaan Propinsi Jawa Timur.

Mudjiono dan Dimyati, Moh. 1991/1992. Strategi Belajar Mengajar. Jakarta : Depdikbud Dirjen Dikti Proyek Pembinaan Tenaga Kependidikan.

Nurhadi, Yasin, Senduk. 2004. Pembelajaran Kontekstual dan Penerapannya dalam KBK. Malang : Universitas Negeri Malang.

Universitas Negeri Malang. 2002. Pedoman Penulisan Karya Ilmiah : Skripsi, Tesis, Desrtasi, Artikel, Laporan Penelitian Edisi ke Empat. Malang. Universitas Negeri Malang.

Yeni, Rachmawati. 2005. Pengembangan Kreatifitas pada Anak Usia TK : Jakarta : Depdiknas Derektorat Jendral Dikti. 